\title{
4 Use and Management of Saline Water for Irrigation in the Near East and North Africa (NENA) Region
}

Redouane Choukr-Allah

\section{CONTENTS}

4.1 Water Scarcity in the Nena Region..............................................................

4.2 Use of Saline Water Resources for Irrigation in Nena Region........................54

4.3 Status and Practices of Saline Water Use in Selected Countries

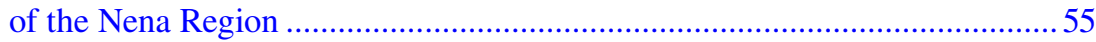

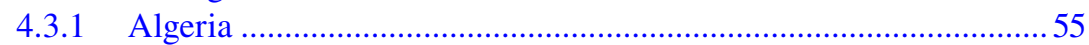

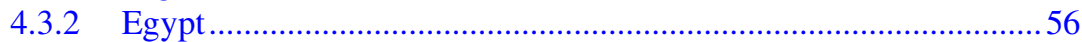

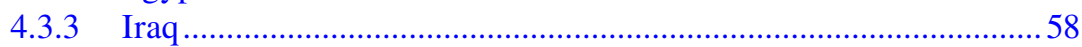

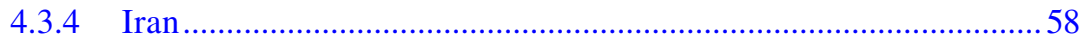

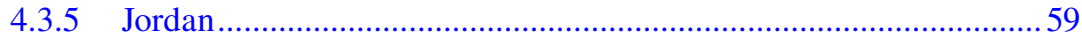

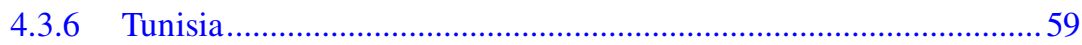

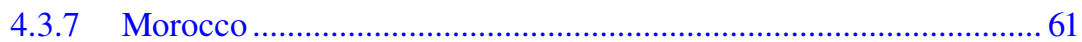

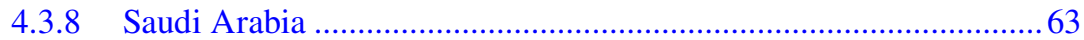

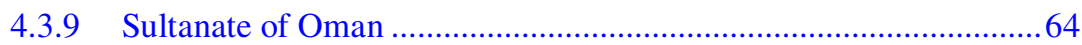

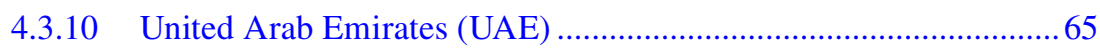

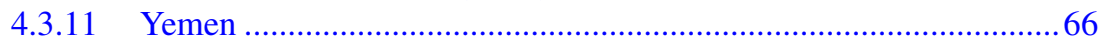

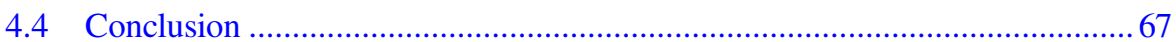

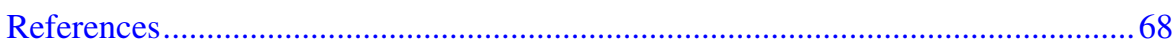

\subsection{WATER SCARCITY IN THE NENA REGION}

The Near East and North Africa (NENA) region covers 19 countries where water scarcity (FAO, 2017) is one of the major challenges (Figure 4.1). This constraint contributes to the degradation of important irrigated areas, affecting the increase of food production needed to address the increase in population. NENA regions account for about $6 \%$ of the world's population with only $1 \%$ of the world's renewable water resources (Mahmoud, 2013; Abu-Zeid, 2013). Most countries of the NENA region, are forced to use non-conventional water resources, including saline water. Saline water is loosely 


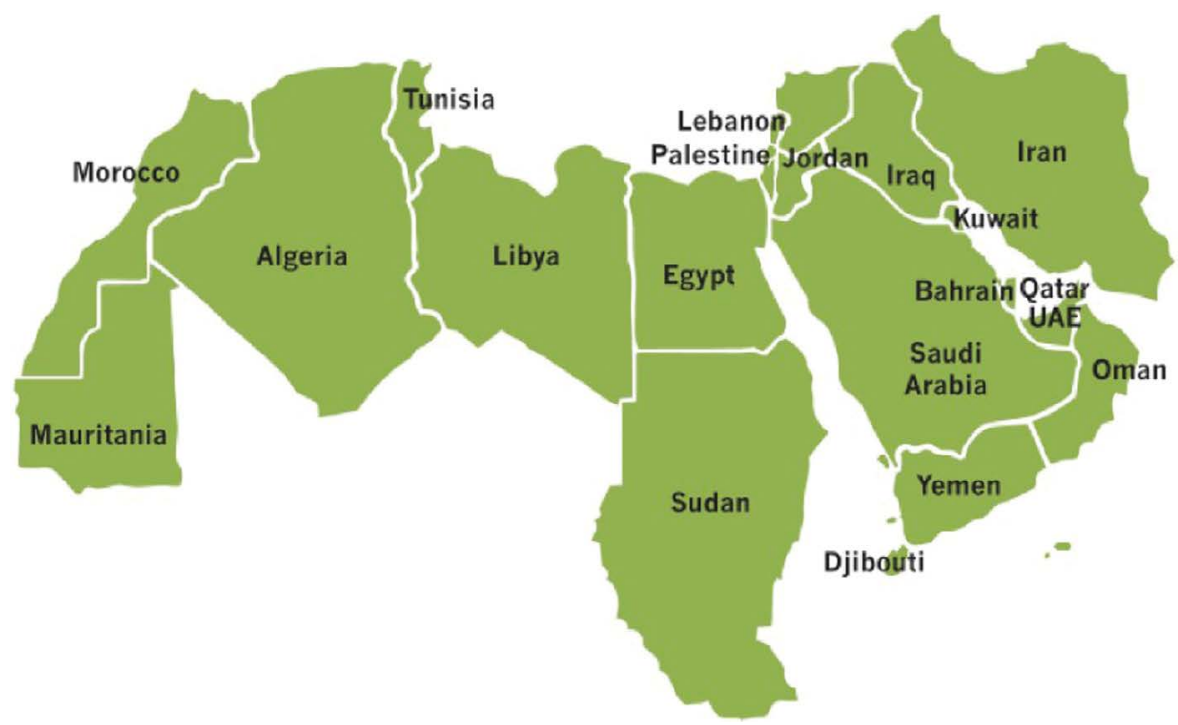

FIGURE 4.1 The Near East and North Africa (NENA) region covers 19 countries from Mauritania to Iran.

defined as water that is more saline than fresh water, but not as saline as seawater. It covers a large range of salinity (FAO, 2018) levels varying from 500 to 35,000 total dissolved solids (TDS) (mg/L). Despite the presence of large amounts of such saline water (e.g. 2 billion $\mathrm{m}^{3}$ of groundwater in Morocco, 13.7 billion $\mathrm{m}^{3}$ in Iran), it is only used in limited amounts for irrigation, even though this water has the potential to be used to grow a number of crops if appropriate management practices are followed. But the successful, long-term use of saline water requires background knowledge of scientific principles combined with proper management in order to minimize the negative impact of salinity on the soil, the crop and the environment.

The NENA region is one of the most water scarce regions in the world (Table 4.1). The average annual precipitation is estimated at $\sim 150 \mathrm{~mm}$. At the same time, the renewable water resources per capita is one of the lowest in the world due

\section{TABLE 4.1}

\section{Total Renewable Water Resources per Capita in NENA Countries}

\section{Country}

Iran, Iraq, Lebanon, Mauretania, Sudan

Egypt, Morocco

Algeria, Jordan, Libya, WBG, Oman, Syria, Tunisia

Bahrain, Kuwait, Qatar, KSA, UAE, Yemen
Total Renewable Water Resources per Capita $\left(\mathrm{m}^{3}\right)$

$$
\begin{gathered}
>1000 \\
500-1000 \\
100-500 \\
<100
\end{gathered}
$$

Source: FAO AQUASTAT Survey - 2008. 
to population growth $\left(690 \mathrm{~m}^{3}\right.$ per capita/year in the region vs. $6400 \mathrm{~m}^{3}$ per capita/ year in the world) (Abu-Zeid, 2013).

There is growing concern over the declining availability of freshwater, and the ever-increasing demands on low quality water.

In general, in arid and semi-arid areas, two realities are recognized. The first is that for all practical purposes fresh water resources are finite and most of the economically viable development of these resources has already been implemented; thus the potential to expand this resource base is marginal. The second is that water quality degradation resulting from urban industrial and agriculture wastewater pollution is reducing the volume of freshwater. Moreover, this is exacerbated with climate change, increasing population, rapid urbanization and the associated expansion of economic activities, all of which require more water, putting tremendous strain on the already limited and fragile resource.

There is no doubt that the water requirements in arid and semi-arid regions will continue to increase significantly during the next decades. The traditional response of increasing water supply to meet higher demands will no longer be adequate in the future. This implies the use, euse and recycling of the non-conventional water resources as an additional water source, particularly in the irrigation sector.

In the majority of the arid and semi-arid regions, the slow progress in agricultural development as well as the decline in food production is not only limited by water shortage, but equally, by rapid soil salinization, bringing nearly $30 \%$ of arable lands (FAO, 2008) out of production (Table 4.2).

\section{TABLE 4.2}

\section{Appropriate Management Practices}

$\begin{array}{ll}\text { Crop Selection and } & \text { - Selection of crops tolerant to salinity and specific ions } \\ \text { Management } & \text { - Identification of critical growing stage affected by salinity } \\ & \text { - Intercropping: irrigating the least salt-tolerant crop first, then using drainage } \\ & \text { water to irrigate another crop which is relatively more salt tolerant. } \\ \text { Water Management } & \text { - Types of irrigation practice (e.g. trickle, furrow, flood, etc.) } \\ & \text { - Application system, method, schedule } \\ & \text { - Monitoring of irrigation water quality } \\ & \text { - Leaching requirements } \\ & \text { - Land drainage } \\ & \text { - using saline drainage water to grow fish, algae and shrimp } \\ & \text { - Levelling, tillage, ploughing, mulching } \\ & \text { - tillage: i.e. the mechanical operation for seedbed preparation, to break up } \\ & \text { surface crust, increase organic matter and nutrient availability } \\ \text { Land Management } & \text { - ploughing: beneficial on stratified soils having impermeable layers laying } \\ & \text { between permeable layers } \\ & \text { - mulching: reduces soil evaporation and temperature } \\ & \text { - Application of chemical or organic amendments (e.g. CaSO }, \text { organic matter) to } \\ & \text { neutralize soil reaction and replace exchangeable sodium by calcium } \\ & \text { - Mixing with sands to increase the permeability of a fine-textured surface soil } \\ \text { - Application of adequate fertilizers, type of fertilizers (preferably acid) } & \text { - Timing and placement of mineral fertilizers } \\ \text { - Regular monitoring of soil salinity } & \end{array}$


Issues related to salinization include the concentration of total salts (salinity) and the concentration of sodium relative to calcium and magnesium (sodicity). Salinity has direct effects on the growth and development of plants. Sodic conditions may cause an important deterioration of the soil physical properties, indirectly affecting crop growth through increased surface crusting, poor water infiltration and reduced root zone aeration.

Salt-affected soils vary in extent by country from 10 to $15 \%$ in Algeria to over $50 \%$ of arable land in Iraq (FAO, Status of the World's Soil Resources: Main Report, 2015). In Iraq and Syria, about 50\% of reclaimed lands in the Euphrates plain are seriously affected by salinization and waterlogging (CAMRE/UNEP/ACSAD, 1996), and in Yemen, approximately $60 \%$ of the 0.5 Mha of irrigated land is slightly to moderately saline, and another $40 \%$ has levels of salinity that prevent farming (FAO, Status of World's Soil Resources: Main Report, 2015). However, a comprehensive assessment on the extent of salt-affected soils globally and in particular the NENA region is lacking.

The successful use of saline water for irrigation requires a basic understanding of the scientific principles affecting the interactions between climate, the applied water, the soil and the crop. Equally important is the application of suitable technology and management practices (Table 4.2) that will facilitate the optional use of this poor-quality water. A higher level of management is needed to successfully use saline water and the adoption of new irrigation management practices will likely be necessary. Since climate, water quality, soil type and crop tolerance to salinity varies from location to location, site-specific and appropriate on-farm management practices need to be developed to attenuate the negative impact of salinity on soil, plant and the environment.

Different types of saline water reuse exist (agricultural drainage water, groundwater and treated wastewater) and are widely used (FAO, AWC, 2018). However, the potential negative impacts of such waters, that include increases in soil salinity, yield reductions, deterioration of soil quality and costs associated with these negative impacts should be considered. Saline water can be used for irrigation directly, mixed or blended with good quality water, used in a cyclic manner (i.e. fresh water followed by saline water) or desalinated prior to irrigation. But to do so effectively, proper management (choice of the adapted crops, irrigation system, leaching, drainage) are needed and care must be exercised to monitor water, soil and crop to ensure long-term deterioration is not taking place.

\subsection{USE OF SALINE WATER RESOURCES FOR IRRIGATION IN NENA REGION}

In the agriculture sector, the use of saline water resources as an additional source for irrigation is highly recommended (Abu-Zeid and Hamdy, 2008), especially in water stressed regions such as the NENA region, to satisfy increasing water demand for irrigation, subsequently expanding the irrigated areas and reducing existing gaps in food and fiber production.

There is ample evidence to illustrate the widespread availability of saline waters and a wide range of experience exists around the world with respect to using them for irrigation under different conditions (Naeimi and Zehtabian, 2011). This evidence 
and experience demonstrate that water of much higher salinities than those commonly used in irrigation can be used effectively to produce selected crops under appropriate field management. However, the use and reuse of such non-conventional water resources for crop production is complex as it is inter-linked with different aspects of the environment, health, industry, agriculture and water resources.

Recognizing these complex inter-linkages, efforts are being directed to the development and use of saline water resources, notably artesian, drainage and saline groundwater water for irrigation. This will certainly result in generating greater amounts of water for irrigation.

It is vital to assess the suitability of such water for irrigation and the subsequent effect on the composition of the soil water and crop (Rhoades, 1972).

\subsection{STATUS AND PRACTICES OF SALINE WATER USE IN SELECTED COUNTRIES OF THE NENA REGION}

The NENA region is faced with a wide range of salinity problems and each country in this region has a unique set of rules and regulations to protect water quality (AbouHadid, 2003). Therefore, it is not surprising that there are also examples of the successful use of saline water in this region. The agricultural practices in the NENA region countries are a matter of experience gained by the farmers depending on water availability and prevailing agricultural conditions and economic factors. Each country has its own experience in producing crops that is specific to its local conditions (FAO and AWC, 2018). Also, each country has its own crop varieties which are a result of its research work and farmers' experiences. Many research and published papers and reports present case studies of the use of saline water in agriculture particularly under conditions of water scarcity in NENA region.

The following is a brief review on saline water use and practices in different NENA countries:

\subsubsection{Algeria}

In Algeria, desertification is putting extreme stress on irrigated agriculture due to the fast rate of soil and water salinization, resulting in the drastic reduction of arable land with productive agricultural potential. This phenomenon is most notable in the western part of the country where major irrigation schemes are located. Out of a total area of 140,000 ha in this part of Algeria, 30\% consists of very saline soils $\left(\mathrm{EC}_{\mathrm{e}}>8\right.$ $\mathrm{dS} / \mathrm{m}$ ). About $90 \%$ of Algeria is in the Sahara Desert where rainfall is rare but at the same time, this arid region has large underground reserves of saline water (Daddi Bouhoun et al., 2013). In the Sahara region, saline groundwater is used for irrigation to grow date palm and alfalfa.

Lands irrigated with saline water are exhibiting salinity problems that differ under different bioclimatic conditions. Meanwhile soil degradation advances, due to the combined action of water salinity, and the insufficiency and/or lack of drainage systems. An assessment of irrigated areas reveals the existence and extent of the salinity level of much of the agricultural land in the West and South of the country (Lahouati and Halim, 2012). 
In the Ouargla region most of palm groves have poor drainage, a shallow water table $(1.6 \mathrm{~m})$ and high salinity $\left(\mathrm{EC}_{\mathrm{w}} 34 \mathrm{dS} / \mathrm{m}\right)$. The drains are the open type and their maintenance is not regular. This situation of managing irrigation-drainage promotes waterlogging in soils. Soil salinity (ECe) ranges between 4.6 and $9 \mathrm{dS} / \mathrm{m}$. This accumulation of salts is due to the dynamic ascending and descending of salts respectively under the effect of capillarity from the shallow groundwater and leaching by irrigation.

\subsubsection{EGYPT}

Egypt is a country with about 5000 years of experience in irrigation. Nevertheless, the country's economy suffers from severe salinity problems due to irrigation with low quality water and poor drainage systems. About $33 \%$ of the cultivated land is already salinized (Abo Soliman and Halim, 2012).

Salinity problems are widespread. Almost $30-40 \%$ of irrigated farmlands are salt affected. It is estimated that $60 \%$ of the Northern cultivated land and $20 \%$ of the Middle and Southern Delta regions have salt-affected soils. In the Nile Valley, i.e. Upper Egypt, salt-affected soils account for about $25 \%$ of the cultivated areas (Figure 4.2). In addition, many areas of the reclaimed desert land adjacent to the

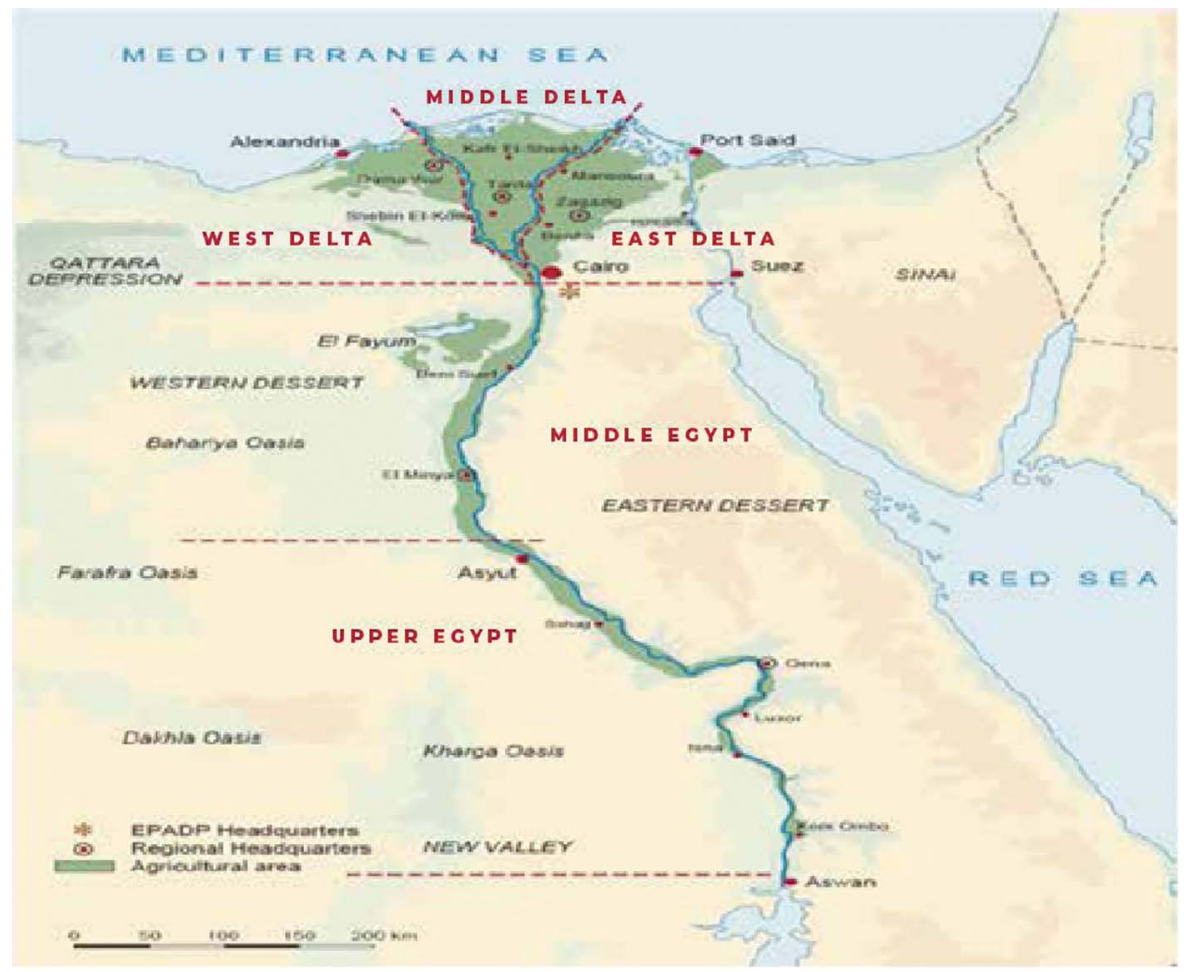

FIGURE 4.2 Upper Egypt, Middle Egypt, Middle Delta, Eastern Delta, and Western Delta. 
Nile Valley and Delta, as well as Sinai and Oases, suffer from waterlogging and high salinity (Saad El-Dein and Galal, 2017).

The needed increase in food production to support the acceleration of population growth $(2.7 \%)$, compels the country to use all sources of water (i.e. drainage water, groundwater and treated sewage water) for the expansion of irrigated agriculture. The drainage water presently used for irrigation amounts to 7 billion $\mathrm{m}^{3}$ per annum and it is likely to increase in the future.

The policy of the Egyptian Government is to use drainage water (up to $\mathrm{EC}_{\mathrm{w}} 4.5$ $\mathrm{dS} / \mathrm{m}$ ) after it is blended with fresh Nile water. Another emerging strategy of alternating different types of water quality has been introduced lately. Research has shown that it is possible to irrigate sensitive crops (maize, pepper, onion, alfalfa, etc.) directly with drainage water in rotation with fresh Nile water, and salt tolerant crops (wheat, cotton, sugar beet, etc.) and moderately sensitive crops (tomato, lettuce, potato, sunflower, etc.) can be irrigated with drainage water but after seedling establishment with fresh Nile water. Based on these results, the Governorate is planning to reclaim 4000 ha using drainage water (Abo Soliman and Halim, 2012).

Crops now grown are mostly forage, cereals and vegetables. In the Delta, saline waters of $\mathrm{EC}_{\mathrm{w}} 2.5$ to $4 \mathrm{dS} / \mathrm{m}$ have been used successfully to grow vegetables under greenhouse conditions. In the New Valley (Oases, Siwa, Bahariya, Farafra, Dakhla and Kharga) there is potential to irrigate about 60,000 ha using groundwater (salinity ranging from $\mathrm{EC}_{\mathrm{w}} 0.5 \mathrm{dS} / \mathrm{m}$ to $6.0 \mathrm{dS} / \mathrm{m}$ ), of which 17,000 ha are already under cultivation. Siwa Oasis has the largest naturally flowing springs in the New Valley. Siwa once contained a thousand springs, of salinity ranging from $\mathrm{EC}_{\mathrm{w}} 2$ to $4 \mathrm{dS} / \mathrm{m}$, which were used successfully to irrigate olive and date-palm orchards, with some scattered forage areas.

The Ministry of Water Resources and Irrigation (MWRI) manages the operation of the pumping stations and the reuse volume is therefore well monitored and recorded. The drainage water salinity ranges between $\mathrm{EC}_{\mathrm{w}} 1.3$ and $4.0 \mathrm{dS} / \mathrm{m}$ except in the most Northern part of the Delta near the Mediterranean Sea coast, where drainage water salinity exceeds $\mathrm{EC}_{\mathrm{w}} 5 \mathrm{dS} / \mathrm{m}$ in some locations. Growers in the Beheira, Kafr-El-Sheikh, Damietta and Dakhlia Governorates have used drainage water directly to irrigate barley, berseem clover, cotton, rice, sugar beet and wheat, although yields are not optimal. However, with good management and crop selection practices, growers have successfully used drainage water with $\mathrm{EC}_{\mathrm{w}} 2-2.5 \mathrm{dS} / \mathrm{m}$ without adverse effects (Rhoades et al., 1992).

Historically, the natural flooding from the Nile not only supplied a continual source of nutrients but also provided a natural flushing of salts to the Mediterranean Sea. Ultimately, the difference in the long-term sustainability of irrigated agriculture in both areas was attributed to salinity control via the leaching of salts.

In the Edkawy region in the delta, tomato plants are cultivated in a special way to use the maximum available rain and natural resources (Abou-Hadid, 2003). After filling the waterlogged soil with sand and arranging the irrigation and drainage systems, the drains and irrigation systems are constructed, and the land is ready for cultivation. The nursery starts in August while the temperature is warm and the growth of the seedlings is quick and uniform. The seedlings stay in the nursery for about 45-60 days and are ready to be transplanted at the end of September or early 
October. Irrigation of the seedlings is kept under control to allow for initial good growth and later appropriate hardening before transplanting. The fields are prepared for cultivation by digging furrows that are short $(10-15 \mathrm{~m})$ and deep enough to avoid the capillary riser

\subsubsection{IRAQ}

The water resources of Iraq depend largely on the surface water of the Tigris and Euphrates rivers and most of the natural renewable water resources of Iraq come from outside the country (Rahi and Halihan, 2018). Both the Tigris and the Euphrates are transnational rivers, originating in Turkey. Between 75 and $85 \%$ of the cropped area is generally planted to grains (mostly wheat and barley). Two-thirds of Iraq's cereal production occurs within the irrigated zone that runs along and between the Tigris and Euphrates rivers. The salinity of the Euphrates in Iraq has increased due to: (1) the decrease in quantity and the increase in salinity of the flow that is entering the country due to the Turkish South-eastern Anatolia Project (GAP), (2) the recharge to the river from Al Tharthar Lake and (3) drainage return flows from irrigated fields within Iraq (Rahi and Halihan 2018). The salinity at the lower regions of the river has increased to a point at which the river water is no longer useful for most municipal or agricultural purposes. Half of the irrigated areas in central and southern Iraq were found to be degraded due to waterlogging and salinity (Abdul Halim and Halim 2012). The absence of drainage facilities and, to a lesser extent, the irrigation practices (flooding) were the major causes of these problems. By 1989 a total of 700,000 ha had been reclaimed at a cost of around US\$2000/ha. According to more recent estimates $4 \%$ of the irrigated areas were severely saline, $50 \%$ moderately saline and $20 \%$ slightly saline. Irrigation with highly saline waters (more than $1500 \mathrm{ppm}$ ) has been practiced for date palm trees since 1977. The use of brackish groundwater is also reported for tomato irrigation in the south of the country (Rahi and Halihan, 2010).

The main option available to mitigate the salinity of the river and to restore the ecosystem is to maintain a minimum instream flow (MIF) (also referred to as environmental flow requirements) (Partow, 2001).

\subsubsection{IRAN}

Salt-affected area in Iran has increased from 15.5 Mha in 1960 to more than 25 Mha in 2008 (Qadir et al., 2008). The volume of marginal water resources is about $12 \%$ of the potential renewable surface water resources of the country. The total area with saline groundwater resources is $350,222 \mathrm{~km}^{2}$ with an annual abstraction volume of $13.7 \mathrm{~km}^{3}$ (Qadir et al., 2008). The use of saline water for crop production has a long history in Iran. Management practices employed by the farmers in using these waters are similar to those practiced with the use of non-saline waters (Cheragi and Halim, 2012). In general, crop production is based on using high inputs of seeds, fertilizer and water. Agronomic practices such as land preparation, irrigation methods and crop rotation are suboptimal. More information on Iran can be found in Chapter 8 (Hazbavi and Silabi, 2021) in this book. 


\subsubsection{JORDAN}

Over $60 \%$ of Jordan's agricultural produce is grown in the Jordan Valley. Here, $4.5 \%$ of the water resources have a salinity over $2000 \mathrm{ppm}$ and $46 \%$ of cultivated soils are moderately to strongly saline $\left(\mathrm{EC}_{\mathrm{e}} 4.5-14.1 \mathrm{dS} / \mathrm{m}\right)$ due to the lack of natural flooding to flush the irrigated lands and leach salts and also, due to the low rainfall and high evaporation.

Brackish water for direct use or after desalination appears to offer the highest potential for augmenting the country's water resources. Brackish springs (67) have been identified in various parts of the country with a total average discharge estimated to be approximately 46 million $\mathrm{m}^{3} /$ year. As such, when referring to statistics about brackish water, the quality, quantity and location of this resource needs to be carefully studied in order to assess its potential for use (Ammari et al., 2013).

Modern desalination technologies applied to brackish water (salinities between 2000 and 8000 ppm pumped from wells at depths between 100 and $150 \mathrm{~m}$ ) offer effective alternatives in a variety of circumstances. In 2015 , there were 52 private desalination plants operated by farmers to desalinate brackish water for irrigation purposes and desalinate about 10 million $\mathrm{m}^{3}$ annually. This irrigation water is used particularly for bananas, a crop of high market value.

The progressive increase in soil salinity in the Jordan Valley is attributed to unsustainable agricultural practices and inputs, a deteriorating quality of irrigation water, the lack of advanced irrigation technologies and efficient drainage systems and improper land management. Also, fertilization and irrigation practices are not based upon sound recommendations that consider the pedoclimatic conditions and crop demands (Al-Rifaee, 2013).

Several trials have been conducted at the research stations of Al-Karamah (Jordan valley) and in Al-Khalidiyah (upper land) to select salt tolerant crop species adapted to the local conditions. These include barley, triticale, wheat, pearl millet, sunflower, sesbania and elephant grass.

The Lower Jordan River defines the international border between Israel and the West Bank on the west and the Hashemite Kingdom of Jordan on the east. Decades of diversion of upstream good-quality water and the direct dumping of saline water and wastewater have severely damaged the river's ecological system. The salinity of the Lower Jordan River has risen significantly to $\sim 5400 \mathrm{mg} \mathrm{Cl} / \mathrm{L}$ in summer (Al-Rifaee, 2013), endangering its capability to supply water, even to saline-resistant crops such as palms, which are one of the main agricultural products of the Jordan Valley (Figure 4.3).

The Jordan Valley Authority partnered with the German Technical Cooperation (GTC) to evaluate crop production in the middle and southern portions of the Jordan Valley with saline water ranging between $\mathrm{EC}_{\mathrm{w}} 2$ and $7 \mathrm{dS} / \mathrm{m}$ over a four year period (GTC, 2003). The goal was to try and develop guidelines for growers in this region that were related to local conditions and practices

\subsubsection{TUNISIA}

Tunisia is among the semi-arid countries faced with serious problems of salinization and water scarcity. Approximately 1.5 Mha, or roughly $10 \%$ of the country's area is 


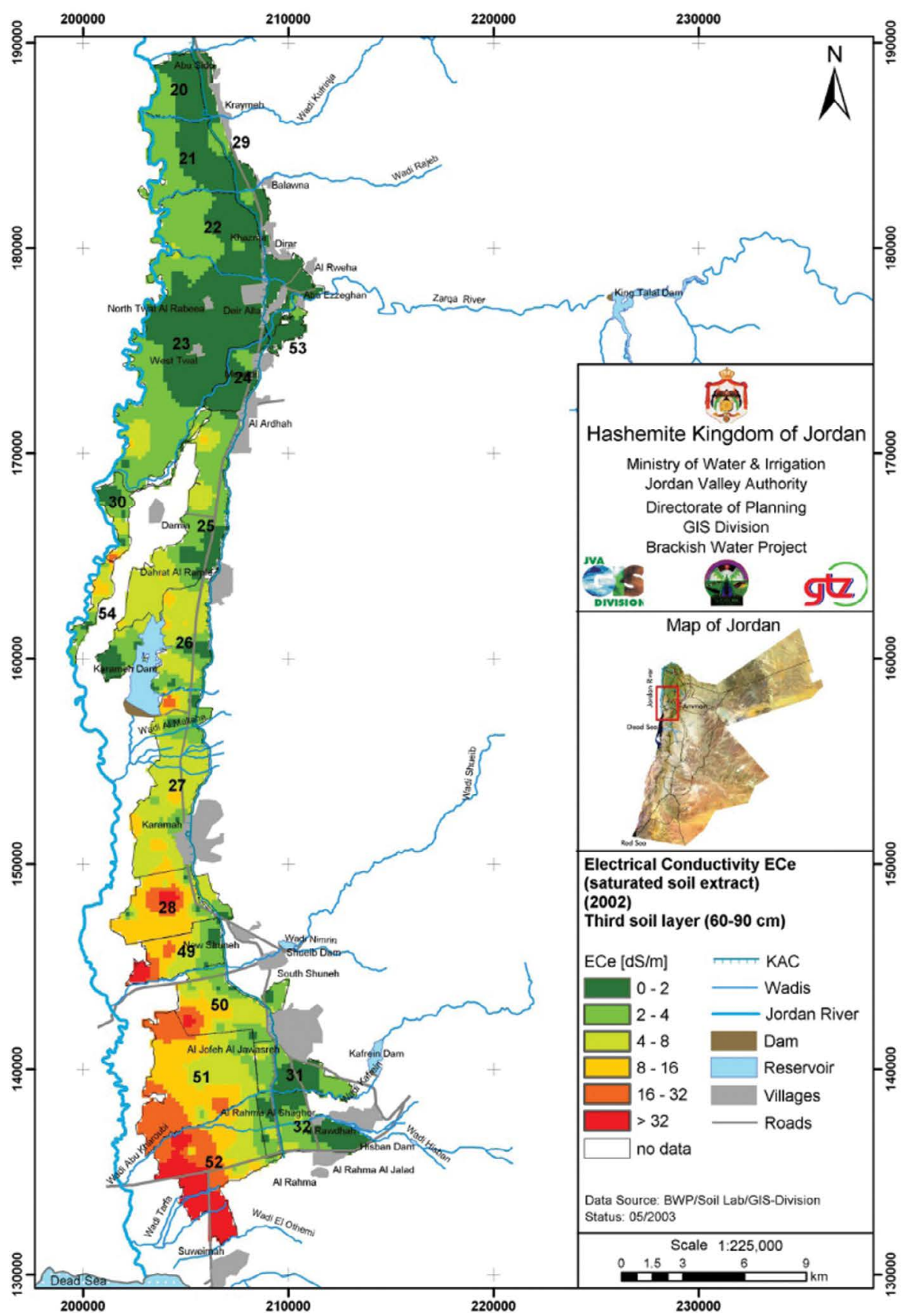

FIGURE 4.3 Soil Salinity map in the Jordan Valley, Jordan (Ammari et al., 2013). 
affected by different degrees of salinity and about $25 \%$ of water resources have a salt concentration exceeding 3g/L (Hachicha, 2007).

As a result, about $50 \%$ of the total irrigated area is considered to be at high risk of salinization (Achour and Halim, 2012). Several initiatives have been implemented since the 1960s by the National Institute of Rural Engineering Water and Forests to evaluate the performance of different management practices including irrigation scheduling, improvements in drainage efficiency, the development of appropriate irrigation systems, physical and chemical techniques (i.e. soil levelling, ploughing, better planting techniques, amino-acid application, etc.), soil amendments and the introduction of salt tolerant crop varieties and new species that could be used to sustainably utilize the irrigated areas that are affected by salinity.

Although the use of saline water for irrigation is a strategy to mitigate water shortage, poor management of saline water for irrigation has resulted in secondary salinization and a series of environmental problems (Kumar et al., 2015; Lei, 2015). These problems will become worse under climate change, in areas of unfavorable soil, with over exploitation of groundwater, with improper cropping patterns and with sea-water intrusion (Heydari, 2019).

The impact of the use of saline water on agricultural production has negatively impacted the environment and the socio-economy of farmers' communities. The main constraint to the use of saline water for agricultural production is primarily the absence of efficient drainage systems in several irrigation command areas. Irrigation with saline water and agricultural development are possible through proper techniques and management of the irrigation water, leaching of salts, adapted farming techniques and choice of salt-tolerant plant varieties.

Based on the importance of the salinity problem in Tunisia, research projects covering some Tunisian regions have been conducted to evaluate the adoption and performance of different management strategies to improve crop production under salt and drought conditions. Research studies related to soil salinity control include: (1) the cultivation of alternative and tolerant-salt varieties such, new cultivars of olive tree, quinoa, jatropha, sesbania and aloe vera, (2) irrigation water management using drip irrigation and sub-surface drip irrigation and (3) improvement of crop tolerance to salinity by application of exogenous proline. The results have shown beneficial effects of different management strategies on the growth and yield of crops, on soil and water properties and the tolerance of the majority of alternative crops to salinity and drought conditions, which has confirmed the possibility of using low quality water for agriculture. However, further research is required in the development of new tools for salinity assessment and the application of biotechnology to improve crop adaptation to limit salt stress effects.

\subsubsection{Morocco}

The sustainability of irrigated agriculture is threatened by the salinization of land and water resources in Morocco. These problems are the result of seepage from unlined canals, inadequate provision of surface and subsurface drainage, poor water management, inappropriate cultural practices and use of saline water for irrigation. Approximately, $30 \%$ of the irrigated area is salt-affected and average yield losses may 


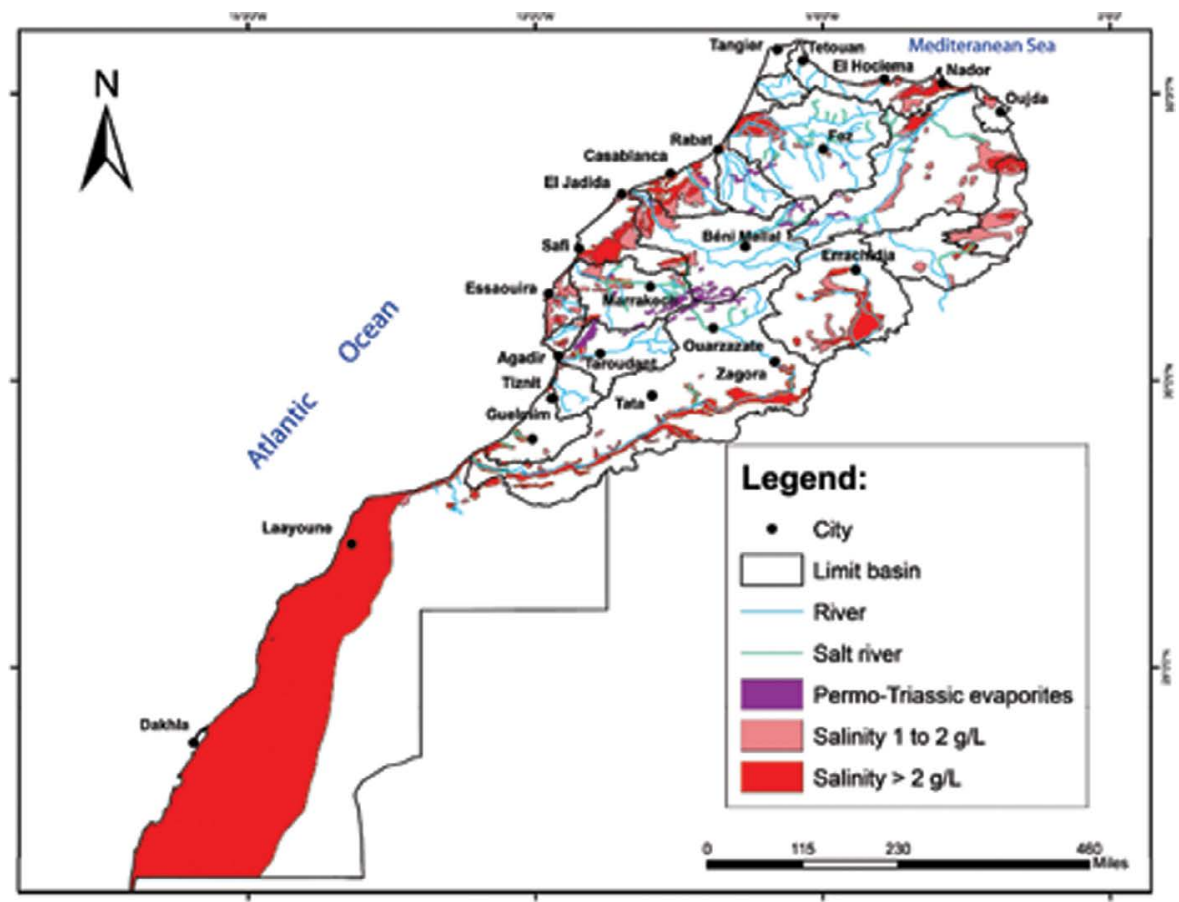

FIGURE 4.4 Spatial distribution of saline aquifers and rivers in Morocco (Hssaissoune et al., 2020).

be as high as $50 \%$. It has been reported that more than 37,000 ha of irrigated land is already affected by salinization (DDGI, 2006). According to FAO (2005),water salinization is the main challenge facing Morocco in terms of water resources quality; out of the 4 billion $\mathrm{m}^{3}$ of groundwater resources about 1.1 billion $\mathrm{m}^{3}$ or $25 \%$ has a salt concentration of between 1 and $2 \mathrm{~g} \mathrm{~L}^{-1}$, and about 1 billion $\mathrm{m}^{3}$ or $27.5 \%$ has a salt concentration exceeding $2 \mathrm{~g} \mathrm{~L}^{-1}$ (Hssaissoune et al., 2020) (Figure 4.4).

IDRC Trials (Figure 4.4) in the Southern Oasis of Tafilalt have focused on the growth of several crops (alfalfa, date palms and okra) using different systems of irrigation (furrow and drip) with conjunctive use of fresh water (from a surface water source) and saline water (groundwater with $\mathrm{EC}_{\mathrm{w}}$ varying from 6 to $10 \mathrm{dS} / \mathrm{m}$ ) (Figure 4.5).
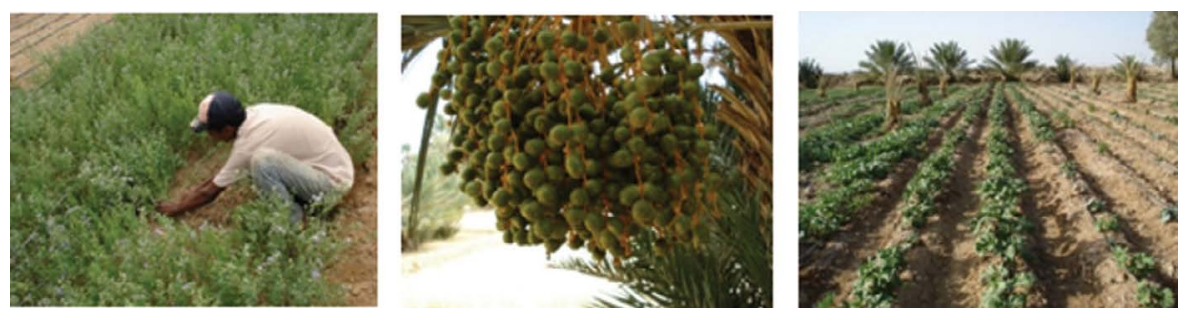

FIGURE 4.5 Alfalfa, date palm and okra grown in south of Morocco with saline water. 
TABLE 4.3

\section{Crop Water Productivity of Different Species Irrigated with Saline Water (7 dS/m) Using Different Irrigation Systems}

\begin{tabular}{lcc} 
& \multicolumn{2}{c}{ Crop Water Productivity $\mathbf{( k g / \mathbf { m } ^ { 3 } )}$} \\
\cline { 2 - 3 } Crops & Drip Irrigation & Surface Irrigation \\
Gombe & 4.31 & 1.36 \\
Watermelon & 6.67 & 3.29 \\
Cabbage & 8.33 & 3.81 \\
Melon & 8.18 & 3.5 \\
Eggplant & 7.6 & 3.13 \\
Pepper & 8.4 & 4.0 \\
Cucumber & 7.0 & 3.13 \\
Potato & 5.95 & 2.43 \\
Alfalfa & 8.09 & 3.1 \\
& & \\
Source: & Choukr-Allah and Halim,2012.
\end{tabular}

The use of drip irrigation allows an average water saving of $3225 \mathrm{~m}^{3} /$ ha for the different crops tested, resulting in a $38 \%$ water saving compared to furrow irrigation.

In the Tafilelt valley, the use of saline groundwater with drip irrigation on local cultivars has allowed farmers to produce reasonable yields. Greatest levels of productivity per cubic meter of water and highest economic gains were achieved with okra, followed by cabbage, watermelon, melon, pepper, cucumber, eggplant and alfalfa (Tables 4.3 and 4.4).

In terms of weights of fodder achieved in a test field, alfalfa was the best crop showing a better response using drip irrigation compared with surface irrigation.

\subsubsection{Saudi Arabia}

About $80-85 \%$ of Saudi Arabia's water supply comes from groundwater and, where groundwater extraction exceeds groundwater recharge, is classified as a non-renewable water resource (Al-Omran et al., 2012). As a result, aquifers are being depleted and the quality of groundwater is becoming more saline. For example, the $\mathrm{EC}_{\mathrm{w}}$ of the groundwater has increased from $1.9 \mathrm{dS} / \mathrm{m}$ in 1983 to $2.8 \mathrm{dS} / \mathrm{m}$ in 1987 in the Saqaquifer. A survey of key groundwater aquifers reveals that $\mathrm{EC}_{\mathrm{w}}$ values range from 1.6 to $8.2 \mathrm{dS} / \mathrm{m}$ with an average of $3.8 \mathrm{dS} / \mathrm{m}$ ( Falatah et al., 1999 as reported by Al-Omran et al., 2012 ). The most popular crops grown with saline water in Saudi Arabia are wheat, sorghum, alfalfa and barley. Saline water is also used to irrigate tomato, onions and watermelon (Al-Omran et al., 2012). Cyclic reuse strategies using saline and desalinized water have been trialed, with tomato and lettuce showing that such methods can be successful for commercial production. It was concluded that 


\section{TABLE 4.4}

\section{Gross Margin and Benefit (MAD/ha) of Several Crops Irrigated with Saline Water $(E C=8$ to $12 \mathrm{dS} / \mathrm{m})$}

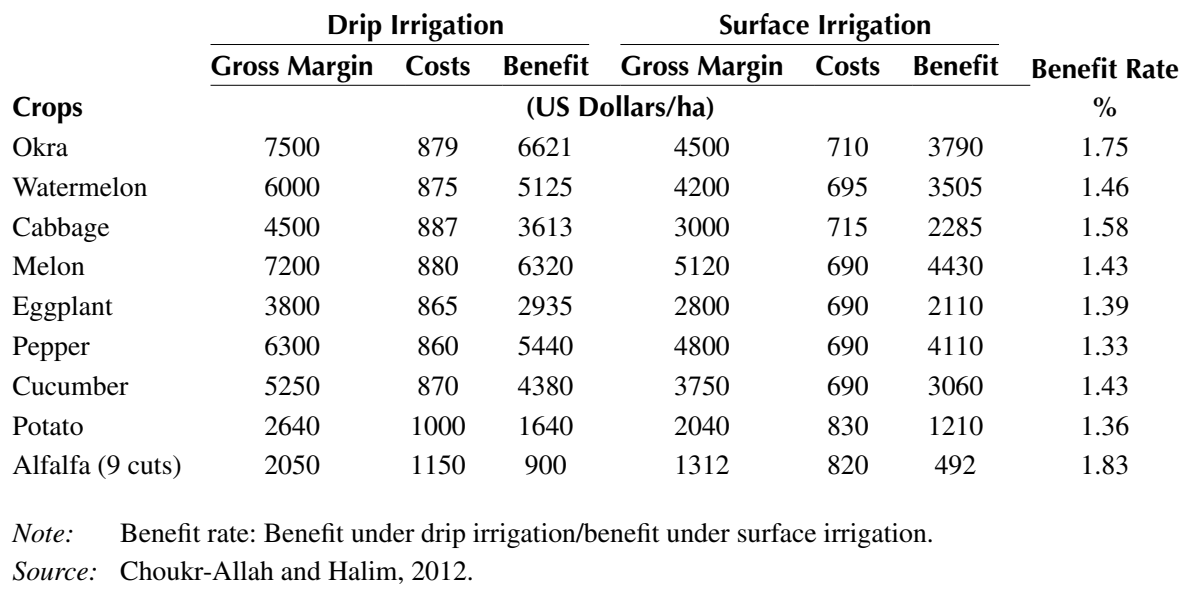

the country has the opportunity to expand the use of treated waste water and saline groundwater for irrigation.

The excessive use of groundwater has created major problems such as the depletion of aquifers and a deterioration of groundwater quality resulting in the conversion the fresh groundwater into saline water. The uncontrolled use of saline water by farmers for irrigating their farms increases soil salinity. Continuous addition of saline water to the soil during the irrigation process, in the absence of good irrigation management practices, undoubtedly leads to salt accumulation in the soil surface layer.

\subsubsection{Sultanate of Oman}

In 2012, the Ministry of Agriculture and Fisheries of Oman entered into a partnership with the International Center for Biosaline Agriculture (ICBA, 2011) to prepare a strategic plan to combat salinity and protect water resources from pollution and salinity in collaboration with other relevant partners in the Sultanate of Oman. The scope of this strategy involved a comprehensive assessment of the current status of the agricultural system in different governorates in the Sultanate of Oman. A survey of 268 farms conducted by ICBA in 2011 found that crop yields and farm profitability decreased substantially with increased soil salinity (ICBA, 2011). Moreover, many salt-sensitive vegetable crops could no longer be grown. The assessment included the extent of the salinity problem, distribution of water resources, productivity of different agricultural systems, the impact of salinity on farmers' income, policy and legislation. Furthermore, the strategy addressed socioeconomic aspects 
and capacity-building needs at all levels. The strategy identified alternative scenarios for sustainable water resources and production systems to bring about a more efficient and sustainable use of natural resources.

The strategy showed that the salinity of water used for irrigation in $40-50 \%$ of the farms is more than $\mathrm{EC}_{\mathrm{w}} 5 \mathrm{dS} / \mathrm{m}$ (ICBA, 2011). Therefore, with the exception of a few salt-tolerant crops such as date palm and Rhodes grass, many crops cannot be successfully grown and the productivities of most other crops are far below their yield potential. Crop varieties that tolerate soil salinity provide acceptable yields in salt affected soils, when crop management practices to reduce soil salinity are employed.

The ICBA analysis also took into account farm size, the expectation being that for similar sized farms, those with higher salinity groundwater would have lower profitability. The weighted average gross margin for the farms benefitting from the best quality water (salinity less than $1500 \mathrm{ppm}$ ) was 2830 USD/acre per year, regardless of the size of the farm. When the salinity was low (between 1501 and $3000 \mathrm{ppm}$ ) the gross margin fell to 2087 USD/acre per year, 74\% of the gross margin for fresh water. For water of medium salinity (between 3001 and $5000 \mathrm{ppm}$ ) the gross margin was 1216.8 USD/acre per year, being $43 \%$ of the Class 1 gross margin. Finally, the gross margin for water of high salinity was 1120 USD/acre per year, being $40 \%$ of the profits achievable with fresh water.

\subsubsection{United Arab Emirates (UAE)}

Soil and water salinity are a significant problem in many parts of the UAE due to intensive desalination, including in agriculture, and seawater intrusion into aquifers. This has resulted in some farmers abandoning their salt-degraded lands as traditional crops fail. The problem poses challenges to national efforts to enhance food security and self-sufficiency through local production. It is estimated that in the United Arab Emirates $34 \%$ of the area is salinized (EAD, 2009).

In part to address these multiple challenges, the International Center for Biosaline Agriculture (ICBA) has worked with local partners to design studies and projects that look for ways to rehabilitate salt-affected areas and make use of saline soil and water resources for food and forage production.

The Government of UAE is supporting ICBA to undertake research on the use of saline water in the agricultural sector in the UAE and at the international level. ICBA conducts research and development programs that aim to improve agricultural productivity and sustainability in marginal environments. ICBA's multi-pronged approach to strengthening the agricultural sector through expanding food production through improved and better access to technology, improved germplasm and policies, is critical to achieve greater water, environment, income and food security. During its second strategic phase (2007-2011), ICBA moved from its initial focus on salinity management to an increased emphasis on water management issues related to agriculture, including marginal water quality.

A three-year study by a team of scientists at ICBA suggested that the growth of halophytic grasses could be a good option for forage production and the rehabilitation of salt-affected lands in the UAE. What is more, they produce higher yields than some traditional grasses like Rhodes grass (Chloris gayana). ICBA studied 
three abandoned salt-degraded farms in Mezaira'a, Madinat Zayed and Ghayathi in the Emirate of Abu Dhabi. When the grasses were established in the first year of the study, the water salinity level on the farms ranged from $\mathrm{EC}_{\mathrm{w}} 14.1$ to $17.4 \mathrm{dS} / \mathrm{m}$. The team tested four halophytic perennial forage grass species namely Distichlis spicata, Paspalum vaginatum, Sporobolus virginicus and S. arabicus for yield and water productivity. Harvested three times a year, the grasses produced average dry biomass yields of 32.6-40.7 t/ha. Average yields in terms of water productivity of $1.7-2.4 \mathrm{~kg}$ of dry matter per cubic meter of water were observed, which is better than that previously reported for Rhodes grass under less saline conditions.

On-farm trials in the Western Region, Abu Dhabi, UAE showed that Paspalum vaginatum produced the highest biomass yields (53.3 t/ha), followed by D. spicata, $S$. virginicus and $S$. arabicus. In terms of water saving - the new grasses can produce the same amount of forage with $44 \%$ less water compared to Rhodes grass (Rao et al., 2017).

Sesbania a short-lived perennial legume and moderate salt tolerant species (threshold $\mathrm{EC}_{\mathrm{w}} 5 \mathrm{dS} / \mathrm{m}$ or $3500 \mathrm{ppm}$ ), yielded up to $175 \mathrm{t} / \mathrm{ha} /$ year (3 cuts) when irrigated with water of $\mathrm{EC}_{\mathrm{w}} 3 \mathrm{dS} / \mathrm{m}$.

Salicornia is a halophytic species, extremely tolerant to salinity and can be irrigated with sea water. It has several uses, including the consumption of young stems - eaten pickled or as a garnish in fresh salads. Seeds contain $30 \%$ oil of high quality hence the species has great potential for the production of edible oil and as for bioenergy feedstock production with seawater irrigation.

\subsubsection{YeMeN}

Irrigated agriculture accounts for about $90 \%$ of the water use in Yemen. Salinity varies across the country and surface waters are generally of much higher quality than groundwater sources (Al-Sabri and Halim, 2012). For example, the salinity in many dams varies between $\mathrm{EC}_{\mathrm{w}} 0.8$ and $1.2 \mathrm{dS} / \mathrm{m}$, except those downstream of large cities where the $\mathrm{EC}_{\mathrm{w}}$ can range between 2.0 and $2.9 \mathrm{dS} / \mathrm{m}$. Groundwater quality, on the other hand, is more complex in nature. In many of the highland and lowland basins the $\mathrm{EC}_{\mathrm{w}}$ can range from 2.0 to $5.0 \mathrm{dS} / \mathrm{m}$, particularly near the Wadis. But the salinity in groundwater near coastal areas can be as high as $8.0-14.0 \mathrm{dS} / \mathrm{m}$ due to seawater intrusion from excessive pumping. Vegetables and fruits are the primary crops that are irrigated in the country. However, irrigation with saline water is mainly used on salt-tolerant crops in the coastal plains, but effluents from wastewater treatment plants are also of poor quality and used for irrigation. Generally, the main crops irrigated with saline water are forages, grains (millet and sorghum), cotton, tobacco, sesame, dates and tomatoes.

Saline waters are available as surface and groundwater and are mainly used by the rock cutting industry in the highlands, as well as for irrigating some tolerant crops mainly in coastal plains. However, the extensive withdrawal of groundwater causes salinity to increase in several parts particularly in the coastal areas. The availability of saline water has not been quantified over the entire country. However, the use of saline water for agriculture in Yemen is about 300 million m³/year, mostly in the Tehama region. 


\subsection{CONCLUSION}

The NENA region has limited freshwater resources and there is a great need to use saline water to meet food and feed demands. In most countries of the NENA region, future projections suggest that it will be necessary to use salt-affected lands in order to meet the food and fiber needs for an expanding population. The severity of salinization differs from one country to the other. However, the use of saline water requires appropriate management to minimize the negative impact of salinity on soil, plant and the environment. About $11.2 \%$ of NENA soils are affected by various levels of salinity and sodicity. Human-induced soil salinization in the region is rapidly increasing, both in irrigated and non-irrigated lands. Salinization drastically reduces crop yields, forcing communities to abandon their agricultural lands. Its negative impacts extend to environmental health and local economies.

Different types of saline water reuse exists (agriculture drainage water, groundwater and treated wastewater) and are widely used. However, one should bear in mind the negative impacts of such waters, such as the increase in soil salinity, yield reductions and cost. Saline water could be used for irrigation directly or desalinated or mixed with treated wastewater. It is highly recommended that good agricultural practices (GAPs) be compiled based on research results using saline water in pilot sites in the NENA region, with the aim of developing guidelines for the safe use of this water.

Guidelines are very important to assist stakeholders and farmers in the use of saline water for irrigation while safeguarding the environment, conserving natural resources, increasing crop productivity/quality and enhancing farm income.

Collaborative research is needed to adapt national programs and policies to turn low-quality water into resources, and to develop the capacity of member countries in the use of saline water. Participatotory research approaches are highly desirable so that extension services can provide local farmers with the know-how on best management practices for irrigation. This information can also be relevant and useful for meeting environmental requirements.

Given the scarcity of water resources, a new paradigm is required that will consider saline water resources as an asset to be managed as part of each country's integrated water resources management framework. This asset would not only increase the availability of water for specific purposes that is hygienically safe, ecologically sustainable and beneficial for the society as a whole, but would also contribute to adaptation to climate change and mitigation of its impacts through the reduction in greenhouse gases.

More effort should be directed towards the establishment of new management and agricultural strategies for the use of saline water that sustain crop production and safeguard the environment. Therefore, in assessing the suitability of saline water for irrigation, it is important to consider the following:

- Crop tolerance to salinity must be known.

- Management practices to prevent or minimize salt accumulation in the soil profile should be put in place.

- Advanced irrigation and drainage technology that are suitable for the use of saline water need to be adopted.

- Saline drainage water can also be used for growing fish, shrimp and algae. 


\section{REFERENCES}

Abdul Halim RK, Halim MK (2012) Status of new development on the use of brackishwater for agricultural production in the Near East: Iraq country report. United Nations Food and Agricultural Organization (FAO), Regional office for the near east (RNE).

Abou-Hadid AF (2003) The use of saline water in agriculture in the Near East and North Africa Region: present and future. Journal of Crop Production 7, 299-323.

Abo Soliman MS, Halim MK (2012) Status of new development on the use of brackish water for agricultural production in the Near East: Egypt country report. United Nations Food and Agricultural Organization (FAO), Regional office for the near east (RNE). doi: $10.2172 / 1169680$.

Abu-Zeid M (2013) Coping with water scarcity in Near East and North Africa: shifting gear. Keynote Speech. FAO Land \& Water Days, 15-18 December, 2013, Amman, Jordan. https://www.slideshare.net/FAOoftheUN/plenary1-keynote-speech-16dec2013az

Abu-Zeid M, Hamdy A (2008) Coping with water scarcity in the Arab world. 3rd International Conference on Water Resources and Arid Environments and 1st Arab Water Forum, 16-19 November, 2008. Saudi Arabia.

Achour H, Halim MK (2012) Status and new development on the use of brackish water for agricultural production in the Near East. Tunisia Country Report. United Nations Food and Agricultural Organization (FAO), Regional office for the near east (RNE).

Al-Omran AM, Aly AA, Halim MK (2012) Status and new development on the use of brackish water for agricultural production in the Near East. Saudi Arabia Country Report. United Nations Food and Agricultural Organization (FAO), Regional office for the near east (RNE).

Al-Rifaee MK (2013) Salinity: Jordan Valley Basin. Power point presentation during Salinity management workshop for the CGIAR Research Program on Water, Land, and Ecosystem (WLE) Jordan, 7-8 December. https://www.researchgate.net/ publication/277803170_Salinity_The_Jordan_Valley_basin.

Al-Sabri A, Halim MK (2012) Status and new development on the use of brackish water for agricultural production in the Near East. Yemen Country Report.

Ammari TG, Tahhan R, Abubaker S, Al-Zu'bi Y, Tahboub A, Ta'any R, Abu-Romman S, Al-Manaseer N, Stietiya MH (2013) Soil salinity changes in the Jordan Valley potentially threaten sustainable irrigated agriculture. Pedosphere 23, 376-384.

CAMRE/UNEP/ACSAD (1996) State of Desertification in the Arab Region and the Ways and Means to deal with it. Council of Arab Ministers Responsible for the Environment (CAMRE), United Nations Environment Programme (UNEP), Arab Center for Studies of Arid Zones and Drylands (ACSAD), Syria, Damascus. 444 pp.

Cheragi SAM, Halim MK (2012) Status and new development on the use of brackish water for agricultural production in the Near East. Iran Country Report. United Nations Food and Agricultural Organization (FAO), Regional office for the near east (RNE).

Choukr-Allah R, Halim MK (2012) Status and new development on the use of brackish water for agricultural production in the Near East. Morocco Country Report. United Nations Food and Agricultural Organization (FAO), Regional office for the near east (RNE).

Daddi Bouhoun M, Saker ML, Hacini M, Boutoutaou D, Ould El Hadj MD (2013) The soil degradation in the Ouargla basin: a step towards the desertification of the palm plantations (north East Sahara Algeria). International Journal of the Environment and Water 2, 93-98.

DDGI (2006). La mise en en oeuvre d'un système d'observation optimisé pour le suivi et le contrôle de l'impact de l'irrigation sur les ressources en sols et eaux dans les périmètres irrigués: Loukkos, Moulouya, Haouz, Souss Massa et Moyen Sebou dites des périmètres de grande irrigation, Direction du Développement et de la Gestion del'Irrigation.

EAD (2009) Soil survey of Abu Dhabi Emirate. Vol. 5. United Arab Emirates, Environment Agency Abu Dhabi. 
Falatah AM, Al-Omran AM, Nadeem MS, Mursi MM (1999) Chemical composition of irrigation groundwater used in some agriculture region of Saudi Arabia. Emirates Journal of Agricultural Science 11, 1-23.

FAO, AWC (2018) Guidelines for Brackish Water Use for Agricultural Production in The Nena Region. Regional Initiative on Water Scarcity for the Near East and North Africa.

FAO (2018) Handbook for saline soil management. www.fao.org/publications.

FAO,(2015) Status of the World's Soil Resources Report - Main Report. http://www.fao.org/ documents/card/en/c/c6814873-efc3-41db-b7d3-2081a10ede50/.

FAO (2008) Water Reports 34. Irrigation in the Middle East region in figures AQUASTAT Survey.

FAO. 2017. Near East and North Africa Regional Overview of Food Insecurity 2016. Cairo, pp. 35. https://www.climamed.eu/wp-content/uploads/files/Near-East-and-NorthAfrica-Regional-Overview-of-Food-Insecurity.pdf.

FAO (2005) L'irrigation en Afrique en chiffres - Enquête AQUASTAT 2005. Food and Agriculture Organization of the United Nations: $p 18$.

German TechincalCoorporation (GTZ) (2003) Guidelines for brackish water irrigation in the Jordan Valley, brackish Water Project, Jordan Valley Authority (JVA), (GTZ), November 2003.

Hachicha Mohamed (2007) Les sols salés et leur mise en valeur en Tunisie. Sécheresse vol. $18, \mathrm{n}^{\circ} 1$, janvier, février, mars 2007. file:///C:/Users/pc/Downloads/Secheresse2007_ Hachicha.pdf

Hazbavi H, Silabi S (2021). Innovations of the 21st century in the management of Iranian saltaffected lands. In: Future of Sustainable Agriculture in Saline Environments. Edited by Negacz, Vellinga, Barrett-Lennard, Choukr-Allah, Elzenga. CRC Press ITaylor \& Francis Group

Heydari N (2019) Water Productivity Improvement Under Salinity Conditions: Case Study of the Saline Areas of Lower Karkheh River Basin, Iran In book: Multifunctionality and Impacts of Organic Agriculture https://www.researchgate. net/publication/335549949_Water_Productivity_Improvement_Under_Salinity_ Conditions_Case_Study_of_the_Saline_Areas_of_Lower_Karkheh_River_Basin_ Iranhttp://dx.

Hssaisoune M, Bouchaou L, Sifeddine A, Bouimetarhan I, Chehbouni A (2020) Moroccan groundwater resources and evolution with global climate changes. Geosciences, 10, 81.

ICBA (2011) Oman Salinity Strategy.Dubai, UAE. http://biosaline.org/projects/ oman-salinity-strategy.

Kumar P, Sarangi A, Singh DK, Parihar SS, Sahoo RN (2015) Simulation of salt dynamics in the root zone and yield of wheat crop under irrigated saline regimes using SWAP model. Agricultural Water Management 148, 72-83.

Lahouati R, Halim MK (2012) Status of new developments on the use of brackish water for agricultural production in the Near East: Algeria country report. United Nations Food and Agricultural Organization (FAO). Regional office for the Near East (RNE).

Lei Li C, Zhao J, Xu Y, Li XS (2015) Effect of saline water irrigation on soil development and plant growth in the Taklimakan Desert Highway shelterbelt. Soil and Tillage Research 146, 99-107.

Naeimi M, Zehtabian G (2011) The review of saline water in desert management International Journal of Environmental Science and Development 2, 6, 474-478.

Qadir M, Qureshi AS, Cheraghi SAM (2008) Extent and characterisation of salt affected soils in Iran and strategies for their amelioration and management. Land Degradation and Development 19, 214-227.

Partow H (2001) The Mesopotamian Marshlands: Demise of an Ecosystem Early Warning and Assessment Technical Report. UNEP/DEWA/TR.01-3 Rev. 1, Division of Early Warning and Assessment, United Nations Environment Program, Nairobi, Kenya. 
Rahi KA, Halihan T (2018) Salinity evolution of the Tigris River. Regional Environmental Change 18, 2117-2127. https://link.springer.com/article/10.1007\%2Fs10113-018-1344-4

Rao NK, McCann I, Shahid SA, Ur Rahman KB, Al Araj B, Ismail S (2017) Sustainable use of salt-degraded and abandoned farms for forage production using halophytic grasses. Crop and Pasture Science 68, 483-492.

Rhoades JD (1972) Quality of water for irrigation. Soil Science 113, 277-284.

Rhoades JD, Kandiah A, Mashali AM (1992) The use of saline waters for crop production. FAO Irrigation and Drainage Paper 48. Food and Agricultural Organization of the United Nations, Rome 133 pp.

Saad El-Dein AA, Galal ME (2017) Prediction of reclamation processes in some saline soils of Egypt. Egypt Journal of Soil Science 57, 293-301. 